\title{
Assessment of Irrigation Water Quality of Pabna District (North-Western Part) of Bangladesh for Securing Risk-Free Agricultural Production
}

\author{
Samia Haque ${ }^{1}$, A. B. M. Sadique Rayhan ${ }^{2}$, Md Mazharul Islam ${ }^{3}$, Zakia Sultana ${ }^{1}$, Aklima Nargis ${ }^{2}$, \\ Masud Hassan ${ }^{1}$ \\ ${ }^{1}$ Department of Soil, Water and Environment, University of Dhaka, Dhaka, Bangladesh \\ ${ }^{2}$ Coastal and ocean Management Institute, Xiamen University, Xiamen, China \\ ${ }^{3}$ Department of Botany, University of Dhaka, Dhaka, Bangladesh
}

Email address:

masudhassanswe1112@gmail.com (M. Hassan)

To cite this article:

Samia Haque, A. B M. Sadique Rayhan, Md Mazharul Islam, Zakia Sultana, Aklima Nargis and Masud Hassan. Assessment of Irrigation Water Quality of Pabna District (North-Western Part) of Bangladesh for Securing Risk-Free Agricultural Production. American Journal of Water Science and Engineering. Vol. 3, No. 6, 2017, pp. 67-71. doi: 10.11648/j.ajwse.20170306.11

Received: September 30, 2017; Accepted: October 24, 2017; Published: November 23, 2017

\begin{abstract}
Agriculture mostly depends on suitable supply of water for irrigation. Before application of water, water quality must be measured because of secure in-toxic food production If the Poor quality of irrigation water is not managed properly then it poses many hazards to plant production. So for the better plant and crop production the quality of the water need to be analyzed properly and improving further management. With the finality to analyze the irrigation water quality (physicochemical parameters), different places of Pabna District were evaluated. Twenty water samples were collected in the winter season (January-march) and then they were examined for temperature, $\mathrm{pH}$, electrical conductivity (EC), total dissolved solids (TDS), sodium adsorption ratio (SAR), soluble sodium percentage (SSP), residual sodium carbonate (RSC), and so on. The study indicates that waters were found within the permissible limits for irrigation purposes. So, The irrigation water samples from surface water, Ground water and deep tube-wells water can be used in agricultural purposes.
\end{abstract}

Keywords: Groundwater, Surface Water and Ground Water, Hydro Geochemistry, Water Quality, Sustainable Agriculture

\section{Introduction}

Bangladesh is an agricultural based economy but it's not totally depends on rainwater. Huge amount of irrigation requires for agricultural practice. Pabna is the north-western district of the country where irrigation is the main criteria for food production except in the rainy season. Irrigation water can come from groundwater, surface water or from nonconventional sources like treated waste water and/or drainage water $[19,21]$. Irrigation helps grow agricultural crops and this crops are dependent on water quality. It has a great importance of this analysis of different parameters of the water of the Pabna district. Due irrigation water is contained a higher salt than potable water sources, it is important to use a good quality of water in to the field. So it is necessary to analyses the parameters whether it is good or not. For a specific use, water quality refers to the characteristics that will influence its suitability. These are physical, chemical and biological characteristics. Irrigation water evaluation is placed on the chemical and physical characteristics [21]. If we use a good quality water, it will give sustainable yield. Therefore, the analysis of the parameters of the water sample is important. Depending on this we will get a good quality of water that will be usable for the growing crops or other respectable uses. Water can be polluted by using different fertilizer and pesticides like diazinon into land for better food production [22].

Soil of the north-western part (floodplain soil) of the country is fertile but in toxic level, so the water quality is also good in ground and surface water $[4,14]$. It covers an area of $2,371.50$ sq. $\mathrm{km}$. with annual average maximum temperature of $36.8^{\circ} \mathrm{C}$ and the minimum of $9.6^{\circ} \mathrm{C}$. The average precipitation is around $3 \mathrm{~mm}$ in December and $300 \mathrm{~mm}$ in august. The annual total rainfall is $1603 \mathrm{~mm}$. The average humidity is $36 \mathrm{~mm}$ in 
February and $76 \mathrm{~mm}$ in august. However, overall humidity is around $57.3 \mathrm{~mm}$ over the year. Pabna forms the south-east boundary of Rajshahi division and Sirajgong and nature district is situated in north-east and North West part of the district. Other borders are cover with Padma and other rivers. Around 2.1 million people's lives in the districts where most of the peoples depends on agricultural production. Its agriculture is mainly dependent on irrigation.

Nevertheless, a detailed investigation regarding the irrigation water quality and its suitability for crops has not yet been done. Therefore, an assessment of irrigation of this district is much more essential for agricultural and food safety to find out whether the concentration of physicochemical properties is tolerate able or not. There are some important factors which are climate related to irrigation and water quality Different crops need different irrigation water quality. The quality of the irrigation water may affect both crop yields and soil physical conditions even if all other conditions and cultural practices [2, 18]. There are three types of characteristics that are physical, chemical and biological which affect the quality of irrigation water [2]. To evaluate the quality of irrigation water, we need to identify the characteristics that are important. Having the water tested by a reputable laboratory is the first step in this process. To avoid problems there must also be sound planning to ensure that the quality of water available is put to the best use. Pabna district lies in the north-western part of Bangladesh.

Agriculture in Pabna District depends on an adequate supply of water for irrigation. If the quality irrigation water is not managed properly then it poses many hazards to plant production. Above mention the goal of this research consist in analyze the irrigation water (physico-chemical parameters), of different places of Pabna District, to find out the better quality of irrigation water and assess the usability of water in irrigation purpose for crop production which is the crying needs of time.

\section{Materials and Methods}

To evaluate the suitability of groundwater for irrigated agriculture of Pabna District a field research was conducted. It is located 24.01 latitude and 89.24 longitude; it is at elevation 19 meters above sea level (Figure. 1). Pabna district water have less chance to polluting water due to floodplain region. Floodplain region have less chances to pollute water than hill soil [23]. On the same way, Padma river has less chance to riverbank erosion than other rivers like Jamuna [24] A total of twenty water samples were collected from various sites Samples were collected from 5 Deep Tubewells Water (DTW), 5 Shallow Tubewells Water (STW), 5 rivers and 5 canals. Each sample was a composite of 10 subsamples to minimize error and heterogeneity. The samples were must use as soon as possible. Before sampling a high density PVC bottles were used and thoroughly cleaned by rinsing with $8 \mathrm{~N} \mathrm{HNO3.} \mathrm{Before} \mathrm{we} \mathrm{started} \mathrm{for} \mathrm{sampling} \mathrm{from}$ a well sufficient amount of water should be pumped out [16]. For the identification the bottles were kept air tight and labeled properly.

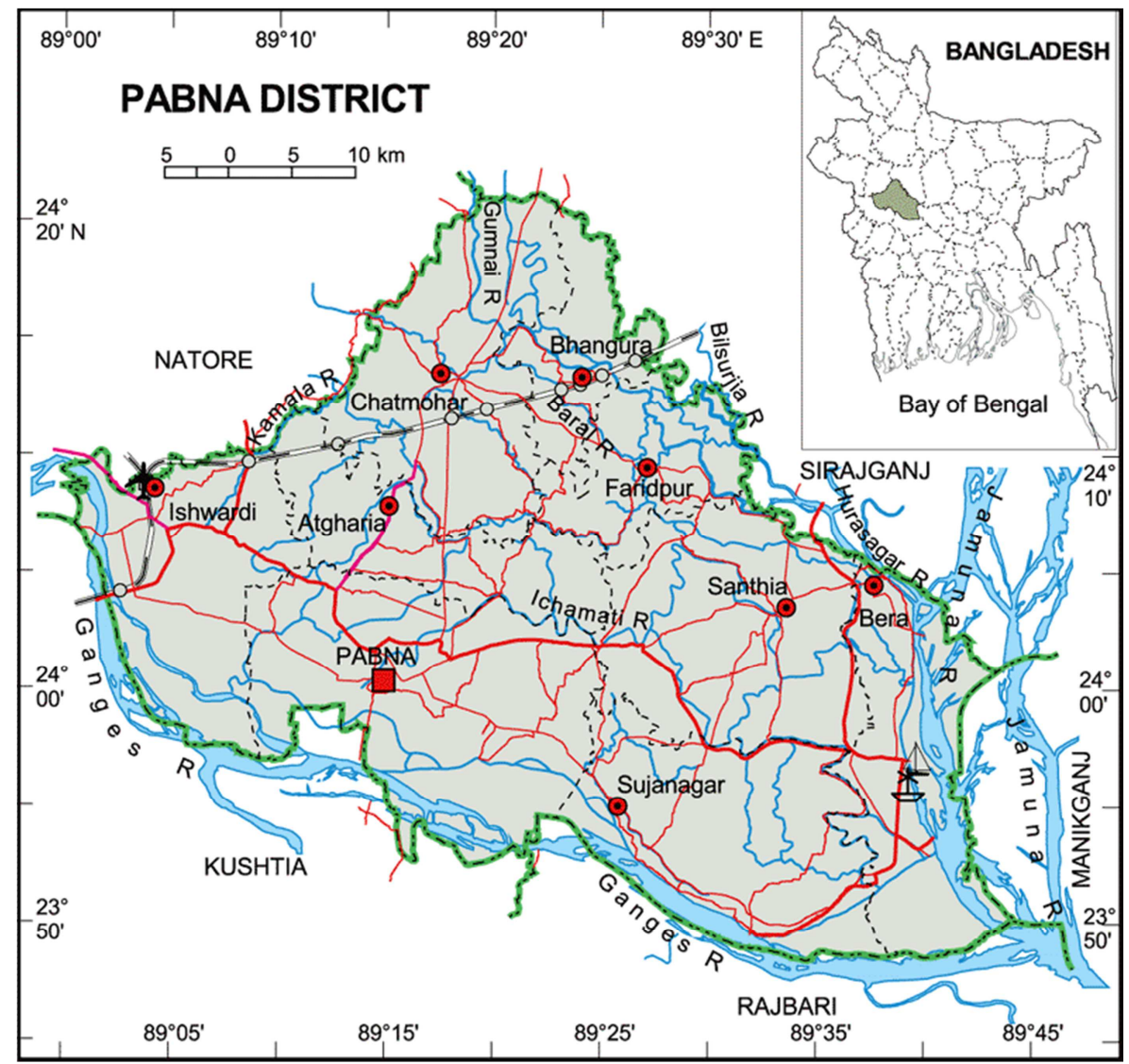

Figure 1. Representation of study area map (Pabna District). 
Variables evaluated. EC, $\mathrm{pH}$ and temperature of the samples were analyzed using portable EC-meter, $\mathrm{pH}$-meter and thermometer, respectively. Also, was analyzed the relation between EC and TDS, Ionic TDS was simply determined by multiplying the measured EC values (in $\mu \mathrm{S} / \mathrm{cm}$ ) by 0.64 . Samples were kept for analysis in the laboratory in a refrigerator. The determination of $\mathrm{Na}+$ and $\mathrm{K}+$ were done by flame photometry [11]; $\mathrm{Ca}^{2+}, \mathrm{Mg}^{2+}$, Fe by visible spectrophotometry [11]; $\mathrm{Cl}^{-}$and $\mathrm{HCO}_{3}$ by titration method [11]; by using the values obtained for, $\mathrm{Ca}^{2+}, \mathrm{Mg}^{2+}$ in $\mathrm{me} / \mathrm{I}$ the sodium adsorption ratio (SAR) was estimated [17]; by the equation using the values obtained for $\mathrm{Na}^{+}, \mathrm{K}^{+}, \mathrm{Ca}^{2+}$, $\mathrm{Mg}^{2+}$ in me/l the soluble sodium percentage was determined; by the equation using the values obtained for $\mathrm{CO}_{2-3}, \mathrm{HCO}_{3}$ in me/l the residual sodium carbonate was determined [7] and by the equation using the values obtained for $\mathrm{Na}^{+}, \mathrm{Ca}^{2+}$ and $\mathrm{Mg}^{2+}$ in me/l the Kelly's ratio was determined [12].

\section{Results and Discussion}

Because the physico-chemical properties has a strong impact of Irrigation water quality and on the productivity of plants and crops, health soils, and the surrounding ecosystems, was important find out the quality of the irrigation water of Pabna District. The results are showed in Table 1, indicated the results of physico-chemical parameters of the study area of Pabna. Table 2 shows the suitability of water quality for irrigation purposes. The EC value of the samples ranges from 318 to $739 \mu \mathrm{S} / \mathrm{cm}$ with an average value of $522.8 \mu \mathrm{S} / \mathrm{cm}$ and standard deviation is $109.63 \mu \mathrm{S} / \mathrm{cm}$. We know that, the EC value of $<700 \mu \mathrm{S} / \mathrm{cm}$ refers the water to 'none' criteria. The $\mathrm{pH}$ value of the samples ranges from 6.0 to 7.9 with an average value of 7.0. Table 1 reveals that the average temperature of the samples was $20.7^{\circ} \mathrm{C}$ and in the range of 18 to $22^{\circ} \mathrm{C}$.

Table 1. Physico-chemical irrigation water quality of different point in Pabna District.

\begin{tabular}{|c|c|c|c|c|c|c|}
\hline Sample no & Sampling area & Sources of sample & Temperature $\left({ }^{\circ} \mathrm{C}\right)$ & $\mathrm{EC}(\mu \mathrm{s} / \mathrm{m})$ & pH & TDS (mg/l) \\
\hline 1 & Atghoria, Akdauta & STW & 19 & 318 & 7.2 & 333 \\
\hline 2 & Atghoria, Debattar & STW & 19 & 435 & 7.4 & 329 \\
\hline 3 & Bera, Chakla & Brahmaputra River & 20 & 455 & 7 & 349 \\
\hline 4 & Bera, kaitola & Brahmaputra River & 19 & 319 & 6.3 & 339 \\
\hline 5 & Bhangura, Dillpashar & DTW & 20 & 633 & 7.9 & 319 \\
\hline 6 & Bhangura, Par Bhangura & Canal & 21 & 555 & 7.3 & 206 \\
\hline 7 & Chatmohor, Foilijana & DTW & 19 & 519 & 7.5 & 249 \\
\hline 9 & Faridpur, Demra & DTW & 20 & 433 & 7.3 & 329 \\
\hline 10 & Faridpur, Hadal & Canal & 19 & 467 & 6 & 329 \\
\hline 11 & Ishurdi, Sara & Padma river & 19 & 567 & 6.2 & 339 \\
\hline 12 & Ishurdi, Paksey & Padma river & 21 & 567 & 6.1 & 326 \\
\hline 13 & Ishurdi, Dashuria & STW & 18 & 517 & 6.1 & 303 \\
\hline 14 & Pabna, Barara & Canal & 20 & 629 & 6.1 & 320 \\
\hline 15 & Pabna, Dapunia & Canal & 20 & 458 & 7.3 & 319 \\
\hline 16 & Pabna, Malanchi & Canal & 21 & 647 & 7.2 & 309 \\
\hline 18 & Santhia, Dropadha & STW & 20 & 529 & 7.2 & 228 \\
\hline 19 & Sujanagar, Dulai & STW & 19 & 428 & 7.3 & 347 \\
\hline \multirow[t]{5}{*}{20} & Sujanagar, Hatkhali & DTW & 22 & 739 & 6 & 489 \\
\hline & Average & - & 20.7 & 522.8 & 7 & 328.25 \\
\hline & Range & - & $18-22$ & $318-739$ & $6.0-7.9$ & $206-489$ \\
\hline & $\mathrm{SD}$ & - & 0.94 & 109.63 & 0.622 & 61.95 \\
\hline & CV\% & - & 4.77 & 20.96 & 8.99 & 18.87 \\
\hline
\end{tabular}

Table 1. Contuined.

\begin{tabular}{|c|c|c|c|c|c|c|c|c|}
\hline Sample no & Sampling area & SAR & SSP\% & RSC me /I & Kalley's Ratio & $\mathrm{Fe}(\mathrm{me} / \mathrm{l})$ & $\mathrm{Cl}$ (me /l) & $\mathrm{HCO}_{3}$ (me /l) \\
\hline 1 & Atghoria, Akdauta & 0.11 & 13.56 & 1.36 & 0.287 & 0.02 & 2.24 & 4.1 \\
\hline 2 & Atghoria, Debattar & 0.13 & 13.53 & 2.37 & 0.286 & 0.023 & 2.38 & 3.33 \\
\hline 3 & Bera, Chakla & 0.17 & 18.89 & 1.41 & 0.387 & 0 & 2.36 & 3.41 \\
\hline 4 & Bera, kaitola & 0.15 & 16.79 & 1.79 & 0.133 & 0.002 & 1.18 & 3.14 \\
\hline 5 & Bhangura, Dillpashar & 0.45 & 14.54 & 2.17 & 0.193 & 0 & 2.9 & 3.13 \\
\hline 6 & Bhangura, Par Bhangura & 0.19 & 23.43 & 1.36 & 0.228 & 0 & 1.24 & 3.09 \\
\hline 7 & Chatmohor, Foilijana & 0.12 & 12.34 & 2.33 & 0.167 & 0.112 & 0.49 & 2.9 \\
\hline 8 & Chatmohor, Bilchalon & 0.13 & 11.59 & 1.37 & 0.127 & 0 & 2.29 & 4.43 \\
\hline 9 & Faridpur, Demra & 0.18 & 14.43 & 2.5 & 0.133 & 0.2 & 3.22 & 2.19 \\
\hline 10 & Faridpur, Hadal & 0.14 & 20.95 & 1.03 & 0.118 & 0.004 & 1.02 & 3.46 \\
\hline 11 & Ishurdi, Sara & 0.19 & 34 & 1.91 & 0.27 & 0.003 & 0.79 & 3.48 \\
\hline 12 & Ishurdi, Paksey & 0.28 & 35.41 & 1.27 & 0.297 & 0 & 0.2 & 5.33 \\
\hline 13 & Ishurdi, Dashuria & 0.13 & 16.57 & 1.32 & 0.197 & 0 & 1.03 & 4.67 \\
\hline 14 & Pabna, Barara & 0.29 & 18.34 & 3.54 & 0.397 & 0 & 2.04 & 5.18 \\
\hline 15 & Pabna, Dapunia & 0.39 & 28.27 & 1.31 & 0.489 & 0.002 & 1.3 & 5 \\
\hline
\end{tabular}




\begin{tabular}{lllllllll}
\hline Sample no & Sampling area & SAR & SSP\% & RSC me /l & Kalley's Ratio & Fe (me /I) & Cl (me /l) & HCO \\
(me /I) \\
\hline 16 & Pabna, Malanchi & 0.39 & 33.12 & 2.87 & 0.789 & 0 & 1.41 & 5.44 \\
17 & Santhia, Karamja & 0.55 & 32.21 & 3.35 & 0.396 & 0 & 2.01 & 4.1 \\
18 & Santhia, Dropadha & 0.32 & 24.43 & 1.33 & 0.28 & 0.005 & 1.15 & 3.27 \\
19 & Sujanagar, Dulai & 0.22 & 24.35 & 2.12 & 0.298 & 0.019 & 1 & 2.59 \\
20 & Sujanagar, Hatkhali & 0.24 & 22.86 & 1.5 & 0.29 & 0 & 1.3 & 3.49 \\
& Average & 0.24 & 21.48 & 1.91 & 0.29 & 0.02 & 1.58 & 3.79 \\
& Range & $0.11-0.55$ & $11.59-35.41$ & $1.03-3.54$ & $0.13-0.79$ & $0.00-0.20$ & $0.20-3.22$ & $2.19-5.44$ \\
& SD & 0.12 & 7.54 & 0.709 & 0.152 & 0.05 & 0.79 & 0.92 \\
& CV\% & 50.9 & 35.1 & 37.1 & 52.8 & 253.7 & 49.8 & 24.2 \\
\hline
\end{tabular}

EC=Elective conductivity; pH: Potential of Hydrogen; TDS: Total Dissolved Solid; SAR: Sodium Adsorption Ratio; SSP: Soluble Sodium Percentage; RSC: Residual Sodium Carbonate;

STW: Shallow Tube well Water;

DTW: Deep Tube well Water.

Table 2. Guideline for interpretation of water quality for irrigation (13).

\begin{tabular}{|c|c|c|c|c|}
\hline \multirow{2}{*}{$\begin{array}{l}\text { Salinity (affects crop water availability) } \\
\text { Potential Irrigation Problem }\end{array}$} & \multicolumn{4}{|c|}{ Degree of Restriction on Use } \\
\hline & None & Slight-Mo & & Severe \\
\hline $\mathrm{EC} \mu \mathrm{S} / \mathrm{cm}$ & $<7000$ & $700-3000$ & $>3000$ & $317-769$ \\
\hline TDS mg/I & $<450$ & $450-2000$ & $>2000$ & $218-529$ \\
\hline \multicolumn{5}{|c|}{ Infiltration (affects infiltration rate of water into the soil. Evaluate using EC and SAR together) } \\
\hline $\mathrm{SAR}=0.3$ and $\mathrm{EC}=$ & $>700$ & & & $<200$ \\
\hline$=3-6=$ & $>1200$ & & & $<300$ \\
\hline$=6-12=$ & $>1900$ & & & $<500$ \\
\hline$=12-20=$ & $>2900$ & & & $>1300$ \\
\hline$=20-40=$ & $>500$ & & & $<2900$ \\
\hline \multicolumn{5}{|l|}{ Specific Ion Toxicity } \\
\hline Sodium $(\mathrm{Na}) \mathrm{meq} / 1$ & $<3$ & & & $0.69-3.09$ \\
\hline Chloride $(\mathrm{Cl}) \mathrm{meq} / \mathrm{l}$ & $<4$ & & & $0.59-5.63$ \\
\hline \multicolumn{5}{|l|}{ Miscellaneous effect } \\
\hline $\mathrm{pH} \quad$ (Normal Range) & $6.5-8.5$ & & & $6.7-7.9$ \\
\hline
\end{tabular}

The TDS values range from $206-489 \mathrm{mg} / \mathrm{l}$ with an average value of $328.25 \mathrm{mg} \backslash \mathrm{l}$. In terms of 'Degree of restrictions on use', the TDS values <450, 450-2000 and $>2000 \mathrm{mg} / \mathrm{l}$ represent the irrigation water as 'none'; 'slight to moderate' and 'severe', respectively (Table 2). The values of SAR range from $0.11-0.55$ with an average value of 0.24 (Table 1). The values of soluble sodium percentage (SSP) range from 11.59 to $35.41 \%$ with an average value of $21.48 \%$ (Table 1 ).

From the Table 1 we get the highest residual sodium carbonate (RSC) value of the irrigation water was 3.54 which was collected from a canal near barara village under Pabna Upazilla. The average value of RSC of the collected irrigation water samples was 1.91. The Kelly's ratio ranged from 0.133 to 0.789 with an average value of 0.29 (Table 1). Iron $(\mathrm{Fe})$ content ranged from 0.00 to $0.20 \mathrm{me} / 1$ with an average value of $0.02 \mathrm{me} / \mathrm{l}$. Chloride $\left(\mathrm{Cl}^{-}\right)$content ranged from 0.20 to $3.22 \mathrm{me} / \mathrm{l}$ with an average value of $1.58 \mathrm{me} / 1$ (Table 1). Bicarbonate ranged from 2.19 and $5.44 \mathrm{me} / 1$ with an average value of $3.79 \mathrm{me} / \mathrm{l}$ (table 1). So, the upper and lower limit of the Kelly's ratio, iron, chlorine, Bicarbonate limit is not toxic for soil health and for production.

Based on the result the temperature and $\mathrm{pH}$ is within the permissible for irrigation purposes. (Doe and UCCC). The EC according to is excellent too good. It is easily presumable from the data in Table 2 that the EC value falls under category 'none'. As EC and TDS values are interrelated so TDS is suitable for irrigation purpose. The SAR of all the irrigation water samples fell under 'excellent' class. (17). The SSP of few samples fell under "Excellent class" The RSC of few samples fell under "Good" class (7). The Kelly's Ratio showed all values were under acceptable range and suitable for irrigation purposes (12). About 10 samples no Fe was detected. Highest Fe concentration was recorded in Foilijana village under Chatmohor Upazilla from DTW. The water sample of DTW near Demra village under Faridpur Upazilla showed the highest value of $\mathrm{Cl}^{-}$. It is evident that the values of $\mathrm{Cl}$ of the study area were within the recommended limit (2) and suitable for irrigation (13). The $\mathrm{HCO}_{3}^{-}$of all the water was suitable for irrigation (2). Most of the values fell into 'slight to moderate'. The B of all samples are within the permissible limits (2).

So, the overall assessment justify the usability of irrigation water of Pabna District. No toxic substance found in the water sampling sources in the present time. So, Farmer and other people can use it without further thinking about the water quality of irrigation water. No toxic chemical and hazardous element cannot found in an excess able level due to absent of over capitalization, Industries, mills and garments factory. But, In the near future government are planning to founded some industry, mills and most importantly Rooppur atomic power plant station which require huge amount of water and energy which discharged polluted water into river, canal and so on. As a consequence ground water, deep and shallow tube well water also can be polluted in the surrounding water that can damage our ecosystem, aquatic life, fish production, food and soil 
quality, biodiversity and human health. So, government should not planned for Rooppur atomic plant in the areas where the ecosystem price is much higher. It can be planned in somewhere else where bio resources is not sufficient. By the way, after a certain time of internal, assessment of irrigation water quality should be measured due to protect our bio resources and sustainability for food production.

\section{Conclusion}

Different physico-chemical properties of irrigation water of Pabna District were matched with the water quality standards set for irrigation. Electrical Conductivity (EC) of collected irrigation water samples fall in the class 'Good' some samples which fall in the 'Excellent' class of EC; SAR, in 'Excellent', SSP in 'Good to Excellent' RSC in 'Good to Marginal' and Fe and $\mathrm{CI}$ contents within the Maximum Allowable Concentration (MAC). On the basis of SAR, RSC, and SSP values, no permeability problem was found to exist in Pabna District. If we gone through the other physical-chemical properties of the Rajshahi division then it will come to know that the physicalchemical properties of Pabna District is quite good at irrigation purposes [1]. The result and quality of water is closely similar with Faridpur District [25]

\section{Competing Interests}

Authors have declared that no competing interests exist.

\section{References}

[1] Alexandra C, Admin MM, Ara S, Akan MMR. Background information for Rajshahi City, Bangladesh. 2006. P. 14-26.

[2] Ayres RS and Westcot DW. Water Quality for Agriculture. Irrigation and Drainage Paper No. 29. Food and Agriculture Organization of the United Nations. Rome. 1985 pp. 1-117.

[3] BADC (Bangladesh Agricultural Development Corporation). 2002. Survey report on irrigation equipment and irrigated area in Boro /2001 season. Bangladesh Agricultural Development Corporation, Dhaka, Bangladesh.

[4] Hassan M, Ahmed AA, Hassan MA, Nasrin R, Rayhan AB, Salehin SM, Rahman MK. Changes of Soil Fertility Status in Some Soil Series of Tista Floodplain Soils of Bangladesh, during 1996-2016. Asian Research Journal of Agriculture. 2017 Jul 13; 5 (3): 1-9.

[5] Cuenca RH. Irrigation system design. An engineering approach. Prentice Hall; 1989.

[6] DOE (Department of Environment). Bangladesh Gazette, No. DA- 1; Department of Environment. Ministry of Environment and Forest. 1997 p. 1324-1327.

[7] Eaton F. M. 1950. Significance of carbonate in irrigation waters. Soil Sci.95: 123-133.

[8] Hasan MA, Ahmed KM, Sracek O, Bhattacharya P, Bromssen MV and Broms S. Arsenic in shallow groundwater of Bangladesh: investigations from three different physiographic settings. Hydrological Journal. 2007; 15, 1507-1522.
[9] Haq SMI and Naidu R. Arsenic in groundwater of Bangladesh: contamination in the food chain. Arsenic contamination in Bangladesh, ITN Bangladesh Dhaka, Bangladesh. 2002; pp.69-72.

[10] Islam MS, Hassan MQ and Shamsad SZKM. Ground water quality and hydrochemistry of Kushtia District, Bangladesh. J. Asiat. Soc. Bangladesh Sci. 199925 (1): 1-11.

[11] Jackson ML. Soil Chemical Analysis. Prentic Hall Inc. Englewood Cliffs, NJ, USA. 1967. pp. 227-267.

[12] Kelly WP. Use of Saline Irrigation Water. Soil Sci. 195395: 355-391.

[13] Marschner H. Mineral Nutrition of Higher Plants. Academic Press, London. 1989 p.340.

[14] Ahmed AA, Hassan M, Ahmed SU, Rahman MK. Fertility Status on Some Tista Floodplain Soils Of Bangladesh. International Journal of Scientific \& Engineering Research. 2017 Jun; 8 (6): 579-82.

[15] Michael AM. Irrigation Theory and Practices. Vikash Publishing House Pvt. Ltd., New Delhi, India.1992; pp. 686-740.

[16] Raghunath HM. 1990. Ground Water. Wiley Eastern Limited, 2nd ed. New Delhi, India. p. 563.

[17] Richards LA. Diagnosis and Improvement of Saline and Alkali Soils, U. S. Department of Agriculture Handbook, Vol. 60, Washington D. C., USA. 1954; p. 160.

[18] Rowe DR and Abdel-Magid IM. Handbook of Wastewater Reclamation and Reuse. CRC Press, Inc. 1995 p. 550.

[19] Hassan M, Hassan R, Mahmud MA, Pia HI, Hassan MA, Uddin MJ. Sewage Waste Water Characteristics and Its Management in Urban Areas- A Case Study at Pagla Sewage Treatment Plant, Dhaka. Urban and Regional Planning. 2017 Jul 14; 2 (3): 13-6.

[20] Sanchez, C. A., \& Silvertooth, J. C. (1996). Managing saline and sodic soils for producing horticultural crops. Hort. Technology. 6 (2), 99-10

[21] Mahmud MA, Hussain KA, Hassan M, Jewel AR, Shamsad SZ. Water quality assessment using physiochemical parameters and heavy metal concentrations of circular rivers in and around Dhaka city, Bangladesh. International Journal of Water Research. 2017 Jun 7; 7 (1): 23-9.

[22] Hassan M, Hassan R, Haque S, Sultana Z, Aktar M. improvement of purification method for diazinon from soil matrix. International Journal of Agriculture, Environment and Bioresearch. 2017 Aug 22; 2 (4): 230-40.

[23] Hassan M, Hassan R, Pia HI, Hassan MA, Ratna SJ, Aktar M. Variation of Soil Fertility with Diverse Hill Soils of Chittagong Hill Tracts, Bangladesh. International Journal of Plant \& Soil Science. 2017 Aug 5; 18 (1): 1-9.

[24] Hassan MA, Ratna SJ, Hassan M, Tamanna S. Remote Sensing and GIS for the Spatio-Temporal Change Analysis of the East and the West River Bank Erosion and Accretion of Jamuna River (1995-2015), Bangladesh. Journal of Geoscience and Environment Protection. 2017 Aug25; 5 (9): 79-92.

[25] Trisha TH, Aktar M, Hassan M, Shamsad S. An Investigation of Geo-Hydro-Chemistry And Physiochemical Properties Of Irrigation Water Quality Of Faridpur District, Bangladesh. 